\title{
Emodin Inhibits ATP-Induced Proliferation and Migration by Suppressing P2Y Receptors in Human Lung Adenocarcinoma Cells
}

\author{
Xia Wang ${ }^{\mathrm{a}}$ Long Li ${ }^{\mathrm{b}}$ Ruijuan Guan ${ }^{\mathrm{a}}$ Danian Zhu ${ }^{\mathrm{a}}$ Nana Song ${ }^{\mathrm{c}}$ Linlin Shen ${ }^{\mathrm{a}, \mathrm{d}}$ \\ aDepartment of Physiology and Pathophysiology, School of Basic Medical Sciences, Fudan University, \\ Shanghai, b Department of Urology, Ninth People's Hospital, Shanghai Jiao Tong University School \\ of Medicine, Shanghai, 'Division of Nephrology, Zhongshan Hospital, Fudan University, Shanghai, \\ 'Shanghai Key Laboratory of Medical Imaging Computing and Computer Assisted Intervention, Fudan \\ University, Shanghai, China
}

\section{Key Words}

Emodin • ATP • A549 cells • Suramin • NF-kB

\begin{abstract}
Background/Aims: Extracellular ATP performs multiple important functions via activation of P2 receptors on the cell surface. P2Y receptors play critical roles in ATP evoked response in human lung adenocarcinoma cells (A549 cells). Emodin is an anthraquinone derivative originally isolated from Chinese rhubarb, possesses anticancer properties. In this study, we examined the inhibiting effects of emodin on proliferation, migration and epithelialmesenchymal transition (EMT) by suppressing P2Y receptors-dependent $\mathrm{Ca}^{2+}$ increase and nuclear factor- $\mathrm{KB}$ (NF-KB) signaling in A549 cells. Methods: A549 cells were pretreated with emodin before stimulation with ATP for the indicated time. Then, intracellular $\mathrm{Ca}^{2+}$ concentration $\left(\left[\mathrm{Ca}^{2+}\right]_{\mathrm{i}}\right)$ was measured by Fluo-8/AM staining. Cell proliferation and cell cycle progression were tested by CCK8 assay and flow cytometry. In addition, wound healing and western blot were performed to determine cell migration and related protein levels ( $\mathrm{BCl}-2$, Bax, claudin-1, NF-KB). Results: Emodin blunted ATP/UTP-induced increase of $\left[\mathrm{Ca}^{2+}\right]_{i}$ and cell proliferation concentration-dependently. Meanwhile, it decreased ATP-induced cells accumulation in the $S$ phase. Furthermore, emodin altered protein abundance of Bcl-2, Bax and claudin-1 and attenuated EMT caused by ATP. Such ATP-induced cellular reactions were also inhibited by a nonselective P2Y receptors antagonist, suramin, in a similar way to emodin. Besides, emodin could inhibit activation of NF-KB, thus suppressed ATP-induced proliferation, migration and EMT. Conclusion: Our results demonstrated that emodin inhibits ATP-induced proliferation, migration, EMT by suppressing P2Y receptors-mediated $\left[\mathrm{Ca}^{2+}\right]_{i}$ increase and NF-KB signaling in A549 cells.

X. Wang and L. Li contributed to the study equally.




\section{Cellular Physiology Cell Physiol Biochem 2017;44:1337-1351 \begin{tabular}{ll|l} 
and Biochemistry 10.1159/000485495 & $\begin{array}{l}\text { O) } 2017 \text { The Author(s). Published by S. Karger AG, Basel } \\
\text { www.karger.com/cpb }\end{array}$
\end{tabular} \\ Wang et al.: The Effect of Emodin on Inhibiting Lung Cancer Cells Progression}

\section{Introduction}

Over one million people die of lung cancer every year worldwide. Primary malignant lung cancers can be classified into small cell lung cancer (SCLC) and non-small cell lung cancer (NSCLC, including adenocarcinoma, squamous cell carcinoma, and large cell carcinoma). NSCLC accounts for $80 \% \sim 85 \%$ of total lung cancers with 5 -year survival rate of $10-15 \%$ [1]. It has been found ATP level in the tumor micro-environment is several hundred even thousand times higher than those in normal tissues [2]. ATP regulates biological functions mainly through purinergic P2 receptors [3], which can be classified into ligandgated ion channel P2X receptors and G-protein coupled P2Y receptors [4]. In human lung adenocarcinoma cells (A549 cells), ATP stimulates cell proliferation by activating P2Y receptors [5]. Activation of P2Y receptors triggers $\left[\mathrm{Ca}^{2+}\right]_{i}$ increase, which is one of the key regulators of not only cell survival but also cell death [6]. In A549 tumor cells, P2Y receptorsinduced proliferation also depends on activation of NF- $\mathrm{kB}$, which can translocate to nucleus [5].. It promotes transcription of downstream target genes such as Bax [7]. Inhibition of NF- $\kappa \mathrm{B}$ signaling pathway suppresses cell proliferation and induces cell cycle arrest in G2/M phase accompanied by regulation of Bcl-2 family proteins (anti-apoptotic protein Bcl-2, proapoptotic protein Bax) in prostate cancer cells [8]. The Bcl-2/Bax ratio is increased in lung cancer cells after stimulation with ATP. Moreover, elevation of Bcl-2/Bax ratio in lung cancer cells may enable tumor cells to survive [9].

Epithelial-mesenchymal transition (EMT) is characterized by the loss of cell-cell adhesion molecules, such as E-cadherin, and up-regulation of mesenchymal markers, such as fibronectin and vimentin [10]. EMT inhibition by down-regulating metastasis associated lung adenocarcinoma transcript 1 (MALAT1) represses lung cancer cell invasion [11]. The intercellular cell-adhesion molecule-1 (ICAM-1), which participates in EMT and tumor invasion is also involved in survival of NSCLC patients and tumor differentiation [12]. Extracellular ATP can decrease expression of the claudin-1, a kind of tight junction protein [13].

Traditional Chinese medicine has many biologic functions such as anti-apoptotic, antilipid aggregation [14]. Emodin, a natural anthraquinone isolated from rhubarb, possesses properties of anti-bacterial [15], anti-inflammatory [16], vasorelaxant [17], and triggering erythrocyte cell membrane scrambling [18]. It can ameliorate diesel exhaust particlesinduced impairment of vascular and cardiac homeostasis in mice [19]. Recent studies have shown emodin can significantly inhibit tumor growth such as melanoma [20], tongue cancer as well as NSCLC [21]. It is reported that emodin suppresses cell growth and triggers cell apoptosis of NSCLC [22, 23]. Extracellular ATP promotes tumorigenesis [24]. In lung cancer cells, ATP promotes cell survival via regulation of $\left[\mathrm{Ca}^{2+}\right]_{i}$ and Bcl-2/Bax ratio [9]. However, it remains unknown if emodin can improve lung adenocarcinoma tumors by inhibiting ATPinduced $\left[\mathrm{Ca}^{2+}\right]_{i}$ increase and its downstream signaling pathway.

To determine the anticancer effect of emodin and its underlying mechanism, we examined the effect of emodin on ATP signaling and its induced proliferation, migration and EMT. We found that emodin could inhibit the ATP-induced proliferation, migration and EMT of A549 cells via inhibiting P2Y receptors-induced $\left[\mathrm{Ca}^{2+}\right]_{\mathrm{i}}$ increase and NF- $\mathrm{\kappa B}$ activation. The new finding may offer a new target for future anticancer therapy.

\section{Materials and Methods}

\section{Chemicals and reagents}

Emodin was purchased from Shanghai future industry Limited by Share Ltd (Shanghai, China). Adenosine 5-triphosphate disodium salt hydrate (ATP) and pyrrolidine dithiocarbamate (PDTC) were purchased from Sigma-Aldrich (St. Louis, MO, USA). Suramin hexasodium salt was purchased from TOCRIS (Bristol, UK). Rabbit anti-Bcl-2, anti-Bax were purchased from Santa Cruz Biotechnology (CA, USA), anti-

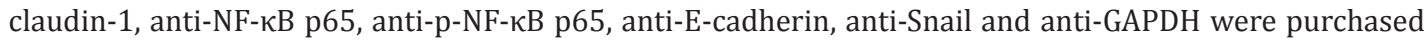




\section{Cellular Physiology Cell Physiol Biochem 2017;44:1337-1351

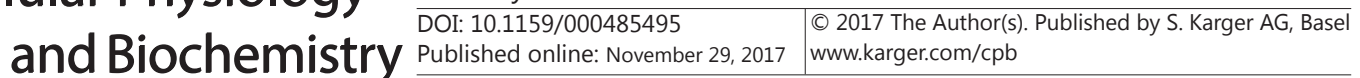 \\ Wang et al.: The Effect of Emodin on Inhibiting Lung Cancer Cells Progression}

from Cell Signaling Technology (Beverly, MA, USA), anti-fibronectin was purchased from ABcam (ABcam, MA, USA), RIPA lysis buffer was purchased from Beyotime Institute of Biotechnology (Haimen, China).

\section{Cell culture}

The human A549 cell was purchased from Fudan IBS Cell Center (Shanghai, China). Cells were cultured in Dulbecco's modified Eagle medium (DMEM, 4.5 $\mathrm{g} / \mathrm{L}$ glucose) (Life Technologies, USA) supplemented with $10 \%$ fetal bovine serum and antibiotics (100 $\mathrm{KU} / \mathrm{L}$ penicillin and $100 \mathrm{mg} / \mathrm{L}$ streptomycin) in an incubator at $37^{\circ} \mathrm{C}$ with $5 \% \mathrm{CO}_{2}$.
Table 1. The target genes and their primer sequences

\begin{tabular}{cc}
\hline Gene & The Sequence of Gene-Specific Primer \\
\hline \multirow{2}{*}{ P2Y1 } & F-GCCGCCGTCTCCTCGTCGTT- \\
& R-CCATTCTGCTTGAACTCAG- \\
P2Y2 & F-CGAGGACTTCAAGTACGTGC- \\
& R-GTTCTCGCTACCAGCCGGCG- \\
P2Y4 & F-GCTGCCTGTGAGCTATGCAG - \\
& R-GAGCTGACGGAGCTGACGTCG - \\
P2Y6 & F-GTTCAGGCTGAGGAGATG- \\
& R-GGAAGCTGATGCAGGTGA- \\
GAPDH & F-TGACTTCAACAGCGACACCCA \\
& R-CACCCTGTTGCTGTAGCCAAA- \\
\hline
\end{tabular}

\section{Quantitative real-time PCR}

Total RNA was extracted from A549 cells with Trizol Reagent (Invitrogen Corporation, CA, USA). Firststrand cDNA was amplified from $0.2 \mu \mathrm{g}$ of total RNA with the ReverTra Ace qPCR RT Kit (Toyobo, Tokyo, Japan). Then the mRNA levels of P2Y1, P2Y2, P2Y4, P2Y6 were analyzed by quantitative real-time PCR (iCyler iQReal-time PCR Detection System, Bio-Rad Laboratories Inc., USA) using SYBR Green Real-time PCR MasterMix (Toyobo, Japan) in a total volume of $20 \mu \mathrm{l}$. Expression levels were normalized to GAPDH. The target genes and their primer sequences were shown in Table 1.

\section{Immunofluorescence staining}

A549 cells were seeded on sterile glass slides. After fixation with 4\% paraformaldehyde for 10 min, the slides were washed with PBS three times. Then cells were blocked with $2 \%$ BSA at room temperature for $1 \mathrm{~h}$ and incubated with primary antibodies (NF- $\mathrm{B}, 1: 100)$ at $4{ }^{\circ} \mathrm{C}$ overnight. After incubation, samples were washed three times with PBS and incubated with secondary antibodies at room temperature for $2 \mathrm{~h}$. The nuclei were stained with DAPI. After washing with PBS, coverslips mounted in $90 \%$ glycerol in PBS, and fluorescence was detected using a Zeiss LSM 710 confocal laser system.

\section{CCK8 assay}

The viability of the A549 cells was determined by the CCK8 assay. Cells were seeded in 96-well plates at $\sim 5 \times 10^{3}$ and treated with medium alone (control) or with emodin and suramin in the presence of ATP (100 $\mu \mathrm{M})$. Then $10 \mu \mathrm{l}$ of CCK8 was added to each well and incubated for $2 \mathrm{~h}$ in an incubator at $37^{\circ} \mathrm{C}$ with $5 \% \mathrm{CO}_{2}$. The absorbance was recorded at a wavelength of $450 \mathrm{~nm}$.

\section{Cell cycle analysis}

For cell cycle analysis, A549 cells were cultured in a $60 \mathrm{~mm}$ dish and pretreated with suramin or emodin 15 min before ATP stimulation. Thereafter, ATP $(100 \mu \mathrm{M})$ was applied to A549 cells for $4 \mathrm{~h}$. Then the cells were washed, fixed, stained with propidium iodide and analyzed for DNA content on a BD FACSCalibur flow cytometer (BD Biosciences).

\section{Western Blot}

Protein was extracted from cultured A549 cell lysates with RIPA lysis buffer with phosphatase inhibitor (Roche). After that protein was loaded into each lane onto SDS-polyacrylamide gels and transferred to a PVDF membrane, the membrane was incubated with primary anti-Bcl-2 antibody (1:1000), anti-Bax antibody (1:500), anti-claudin-1 antibody (1:1000), mouse anti-GAPDH polyclonal antibody (1:2000) at $4^{\circ} \mathrm{C}$ overnight, mouse anti-GAPDH polyclonal antibody (1:2000 dilution). HRP-labeled Goat Anti-Rabbit IgG $(\mathrm{H}+\mathrm{L})(1: 1000$ dilution) and HRP-labeled Goat Anti-Mouse IgG $(\mathrm{H}+\mathrm{L})(1: 2000$ dilution) antibodies were used as the secondary antibodies. The optical density was normalized to that of GAPDH (1:1000, Beyotime), which represented as relative optical density.

$\left[\mathrm{Ca}^{2+}\right]_{i}$ Measurement

A549 cells were grown at 50\%-60\% confluence on $25-\mathrm{mm}$ diameter circular glass coverslips. Then, cells were pretreated with emodin or suramin at indicated concentrations for $10 \mathrm{~min}$. Next, cells were loaded 


\section{Cellular Physiology Cell Physiol Biochem 2017;44:1337-1351

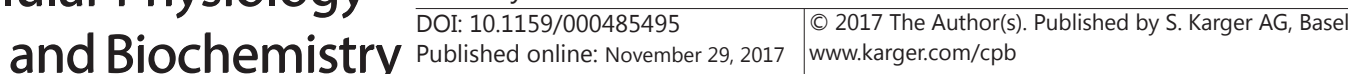 \\ Wang et al.: The Effect of Emodin on Inhibiting Lung Cancer Cells Progression}

with $10 \mu \mathrm{M}$ Fluo-8/AM and $0.02 \%$ pluronic F-127 for $30 \mathrm{~min}$. After washing with normal physiological solution (NPSS) containing $1 \mathrm{mmol} \mathrm{CaCl}, 140 \mathrm{mmol} \mathrm{NaCl}, 5 \mathrm{mmol} \mathrm{KCl}, 1 \mathrm{mmol} \mathrm{MgCl}, 10 \mathrm{mmol}$ glucose, 5 mmol Hepes, coverslip with cells was mounted into the recording chamber. The fluorescence signals were recorded by Zeiss 710 confocal laser system and $\left[\mathrm{Ca}^{2+}\right]_{\mathrm{i}}$ changes were showed as a ratio of fluorescence (F1/ F0).

\section{Wound healing assay}

A549 cells were seeded in a six-well plate and pretreated with emodin and suramin then stimulated with ATP for the indicated time. Three parallel lines were drawn on the underside of each well to demarcate the wound areas for analysis. A scratch was made in the center of the well using a sterile $1000 \mu \mathrm{l}$ micropipette tip before the cells were fully confluent. The wounds were observed using bright field microscopy (Olympus, Tokyo, Japan) after the scratch at $0 \mathrm{~h}, 6 \mathrm{~h}, 12 \mathrm{~h}, 24$ h. Images were analyzed by Image J software. The rate of migration $=($ scratch widths before migration-scratch widths after migration)/ scratch widths before migration $\mathrm{x} 100 \%$.

\section{Statistical analysis}

Data are expressed as mean \pm SD. The significance of differences among groups was evaluated by one-way ANOVA test. A value of $\mathrm{p}<0.05$ was considered statistically significant.

\section{Results}

Effects of emodin on ATP/UTP-induced $\left[\mathrm{Ca}^{2+}\right]_{i}$ increase in A549 cells.

We detected the expression of P2Y receptors in A549 cells using RT-PCR (Fig. 1A). As expected, mRNA level of P2Y2 and P2Y6 was more than P2Y1 and P2Y4. Then the effect of emodin on ATP-induced $\left[\mathrm{Ca}^{2+}\right]_{i}$ increase was examined. Application of ATP $(100 \mu \mathrm{M})$ evoked a

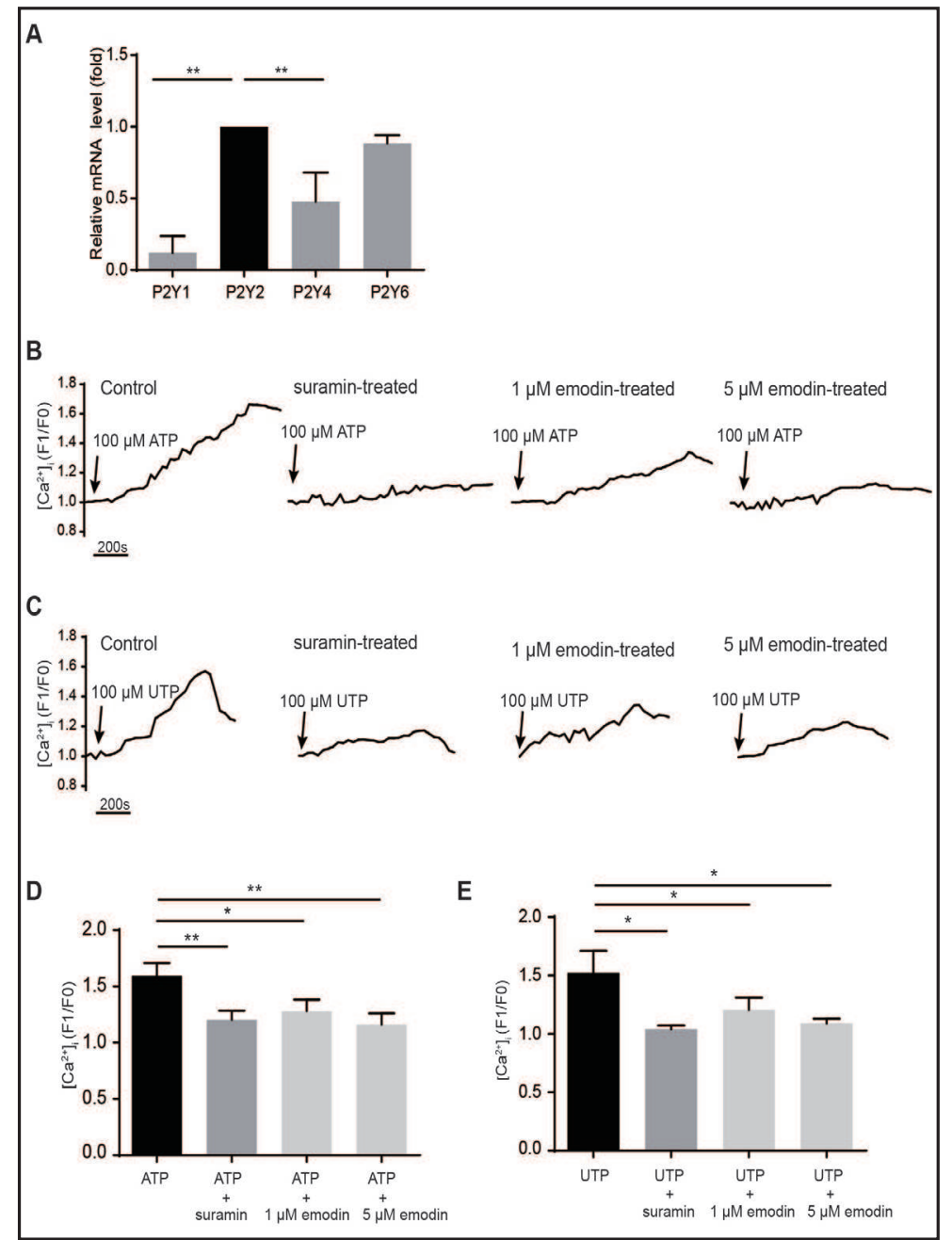

Fig. 1. Emodin inhibited ATP/UTP-induced $\mathrm{Ca}^{2+}$ increase in a concentration-dependent manner.(A) mRNA level of P2Y1, P2Y2, P2Y4, P2Y6 were measured by real-time qualitative PCR. The expression of P2Y2 and P2Y6 receptor were much higher than that of P2Y1 and P2Y4 in A549 cells. Values are mean $\pm S D, n=6,{ }^{* *} p<0.01$. (B) Representative tracings of $\left[\mathrm{Ca}^{2+}\right]_{i}$ for cells treated with ATP $(100 \mu \mathrm{M})$ alone and cells preincubated with suramin $(100 \mu \mathrm{M})$ or emodin $(1$ and $5 \mu \mathrm{M})$. Suramin and emodin was added 15 min before the addition of ATP. Arrows indicated applications of ATP. (C) Representative $\left[\mathrm{Ca}^{2+}\right]_{\mathrm{i}}$ traces for stimulating A549 cells with UTP $(100 \mu \mathrm{M})$ after pretreatment with suramin or emodin for $15 \mathrm{~min}$. Arrows indicated the application of UTP. (D-E): Summarized data showing ATP and UTP-induced $\left[\mathrm{Ca}^{2+}\right]_{\mathrm{i}}$ rise after application of ATP or UTP alone and in the presence of emodin or suramin. Values are mean $\pm \mathrm{SD}, \mathrm{n}=6,{ }^{*} \mathrm{P}<0.05$, ${ }^{* *} \mathrm{p}<0.01$. 


\section{Cellular Physiology Cell Physiol Biochem 2017;44:1337-1351 \begin{tabular}{l|l} 
DOI: 10.1159/000485495 & ( ) 2017 The Author(s). Published by S. Karger AG, Basel
\end{tabular}

Fig. 2. Emodin suppressed ATP-induced cell proliferation.(A) A549 cells were stimulated with ATP for $4 \mathrm{~h}$, $8 \mathrm{~h}, 12 \mathrm{~h}, 16 \mathrm{~h}, 20 \mathrm{~h}$ and $24 \mathrm{~h}$. The cell viability was measured by CCK8 assay. Viability of cells increased $4 \mathrm{~h}$ after ATP stimulation and then decreased and reached the baseline at $12 \mathrm{~h}$. (B) The cell viability of A549 cells was measured after treated with emodin of $0.1,0.5,1$, 5, $10 \mu \mathrm{M}$ for $4 \mathrm{~h}$. Cells treated with DMSO served as control. Low doses of emodin had no effect on cell viability, while high dose of emodin $(10 \mu \mathrm{M})$ inhibited cell viability slightly. (C)

Cells were pre-cultured with suramin $(100 \mu \mathrm{M})$ or emodin at different concentrations $(0.5,1,5 \mu \mathrm{M})$ before ATP $(100 \mu \mathrm{M})$ stimulation. Either suramin or emodin attenuated the proliferating effect of ATP. Additionally, the inhibitory effect of emodin on ATP- induced proliferation was dose-dependent. (D-E) Cell cycle profiles were further evaluated by flow cytometry. The G0/G1, S, G2/M cell populations were assessed after propidium iodide staining. Stimulation with ATP caused more cell populations in the S and G2/M phases. While pretreatment with either emodin or suramin eventually led to an accumulation of cells in the G0/G1 phase and decreased cell population of $\mathrm{S}$ and G2/M phases. Values are mean $\pm \mathrm{SD}, \mathrm{n}=6,{ }^{*} \mathrm{P}<0.05,{ }^{* *} \mathrm{P}<0.01, * * *$ $\mathrm{p}<0.001$. Abbreviations: S, DNA duplication phase; G0/G1, gap between end of M-phase and start of S-phase; G2, gap between end of S-phase and start of M-phase.

rapid increase in $\left[\mathrm{Ca}^{2+}\right]_{\mathrm{i}}$ in A549 cells (Fig. 1B). ATP-evoked $\left[\mathrm{Ca}^{2+}\right]_{\mathrm{i}}$ increase was significantly reduced by pretreatment with emodin at $1,5 \mu \mathrm{M}$. UTP, a selective agonist for P2Y receptor, also induced $\left[\mathrm{Ca}^{2+}\right]_{\mathrm{i}}$ response in A549 cells [25]. Thus, UTP was used as a positive control to determine the potency and specificity of emodin. As shown in Fig. 1C, UTP-triggered $\left[\mathrm{Ca}^{2+}\right]$ increase was also remarkably inhibited by emodin dose dependently. Therefore it was well established that P2Y receptors are highly expressed in A549 cells. These results indicated that emodin could suppress ATP/UTP-induced $\left[\mathrm{Ca}^{2+}\right]_{\mathrm{i}}$ increase in A549 cells.

\section{Emodin inhibited ATP-induced proliferation.}

Since ATP-induced proliferation time dependently, cells were treated with ATP for $4,8,12,16,20$ and $24 \mathrm{~h}$. Cell proliferation degree peaked at $4 \mathrm{~h}$ after ATP stimulation and then reduced (Fig. 2A). Thus, $4 \mathrm{~h}$ was selected as the best stimulating time. We then tested the effect of emodin on cell viability of A549 cells. Cells were treated for $4 \mathrm{~h}$ with increasing doses of emodin from $0.1 \mu \mathrm{M}$ to $10 \mu \mathrm{M}$. Emodin at a concentration of $\leq 5 \mu \mathrm{M}$ had no discernible effect, however, $10 \mu \mathrm{M}$ caused a very mild but significant reduction in cell viability (Fig. 2B). To investigate the inhibitory effect of emodin on extracellular ATPinduced proliferation, cells were pretreated with emodin $(0.5,1,5 \mu \mathrm{M})$ or suramin $(100 \mu \mathrm{M})$ and then stimulated with ATP $(100 \mu \mathrm{M})$. As shown in Fig. $2 \mathrm{C}$, stimulation with ATP evidently 


\section{Cellular Physiology Cell Physiol Biochem 2017;44:1337-1351

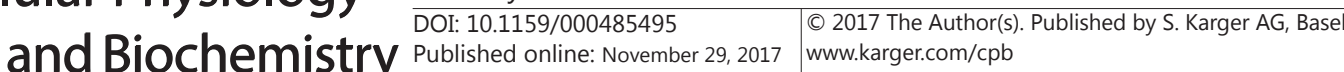

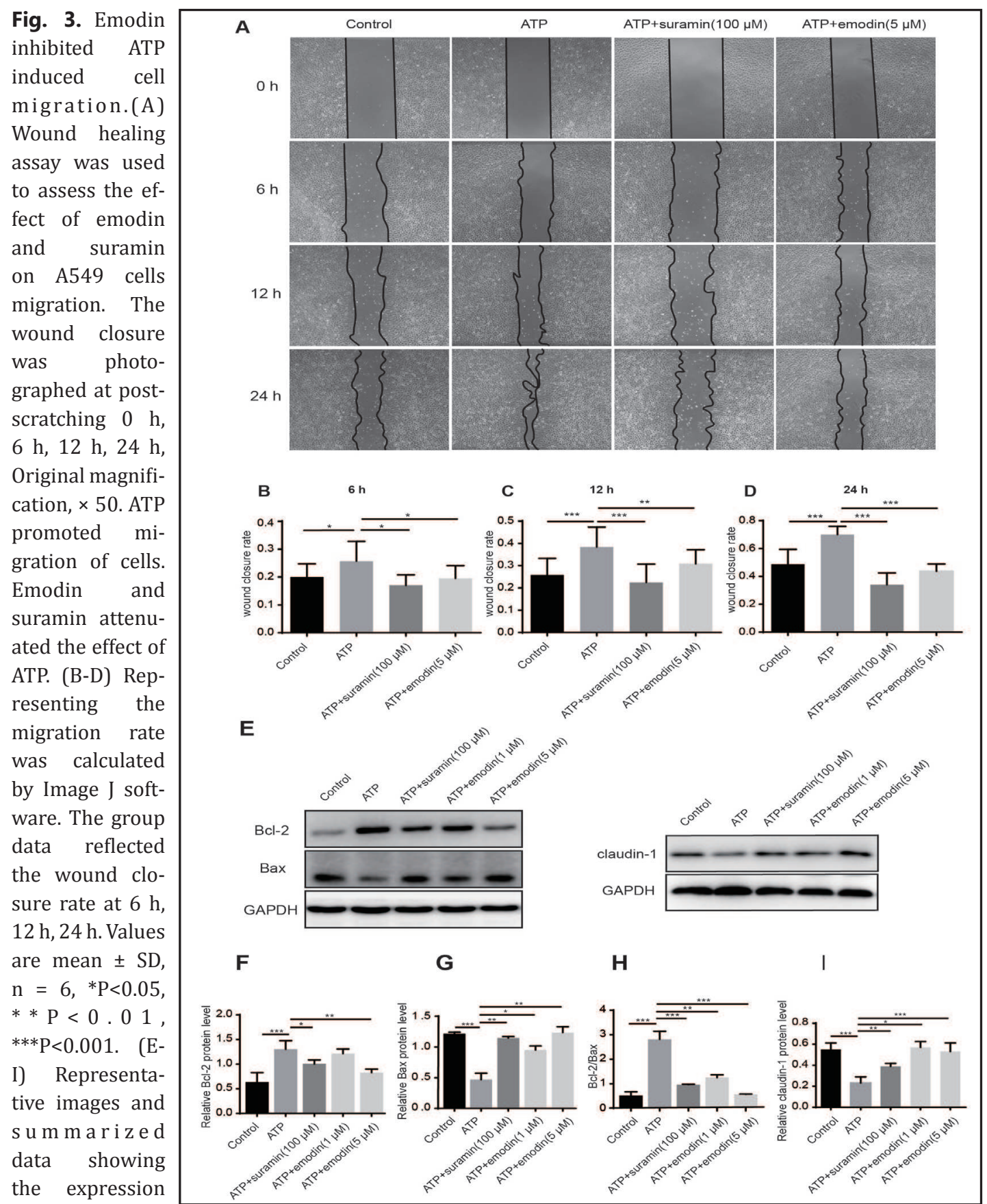

levels of $\mathrm{Bcl}-2$,

Bax, claudin-1. The expression level of Bcl-2, Bax, claudin-1 were normalized to GAPDH level in the same sample. ATP increased the expression of Bcl-2 and decreased the expression of Bax and claudin-1. Similar to suramin, emodin inhibited the effect of ATP. Values are mean $\pm \mathrm{SD}, \mathrm{n}=6,{ }^{*} \mathrm{P}<0.05,{ }^{* *} \mathrm{P}<0.01,{ }^{* * *} \mathrm{P}<0.001$.

enhanced A549 cells proliferation. However, emodin inhibited ATP-induced proliferation in a concentration-dependent manner with the most significant inhibition at concentration of 5 $\mu \mathrm{M}$. Besides, ATP-induced cell proliferation was suppressed by suramin in a similar fashion. To further confirm the effect of emodin on the A549 cells proliferation, we analyzed cell cycle by propidium iodide staining. The data showed that stimulation with ATP caused more cell 


\section{Cellular Physiology Cell Physiol Biochem 2017;44:1337-1351

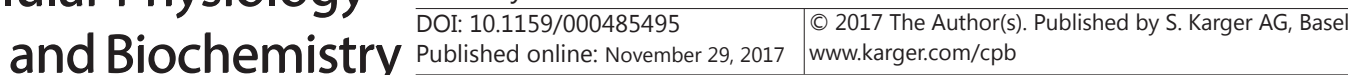

Fig. 4. Emodin inhibited ATP-induced EMT in A549 cells.(A) The protein levels of E-cadherin, fibronectin and Snail were measured by western blot. ATP decreased the expression of E-cadherin and increased the expression of fibronectin and Snail. Emodin as well as suramin inhibited the effect of ATP. (B-D) The group data from A. The expression level of E-cadherin, fibronectin and Snail were normalized to GAPDH level in the same sample. Values are mean $\pm \mathrm{SD}, \mathrm{n}=6,{ }^{*} \mathrm{P}<0.05$, **P $<0.01$.

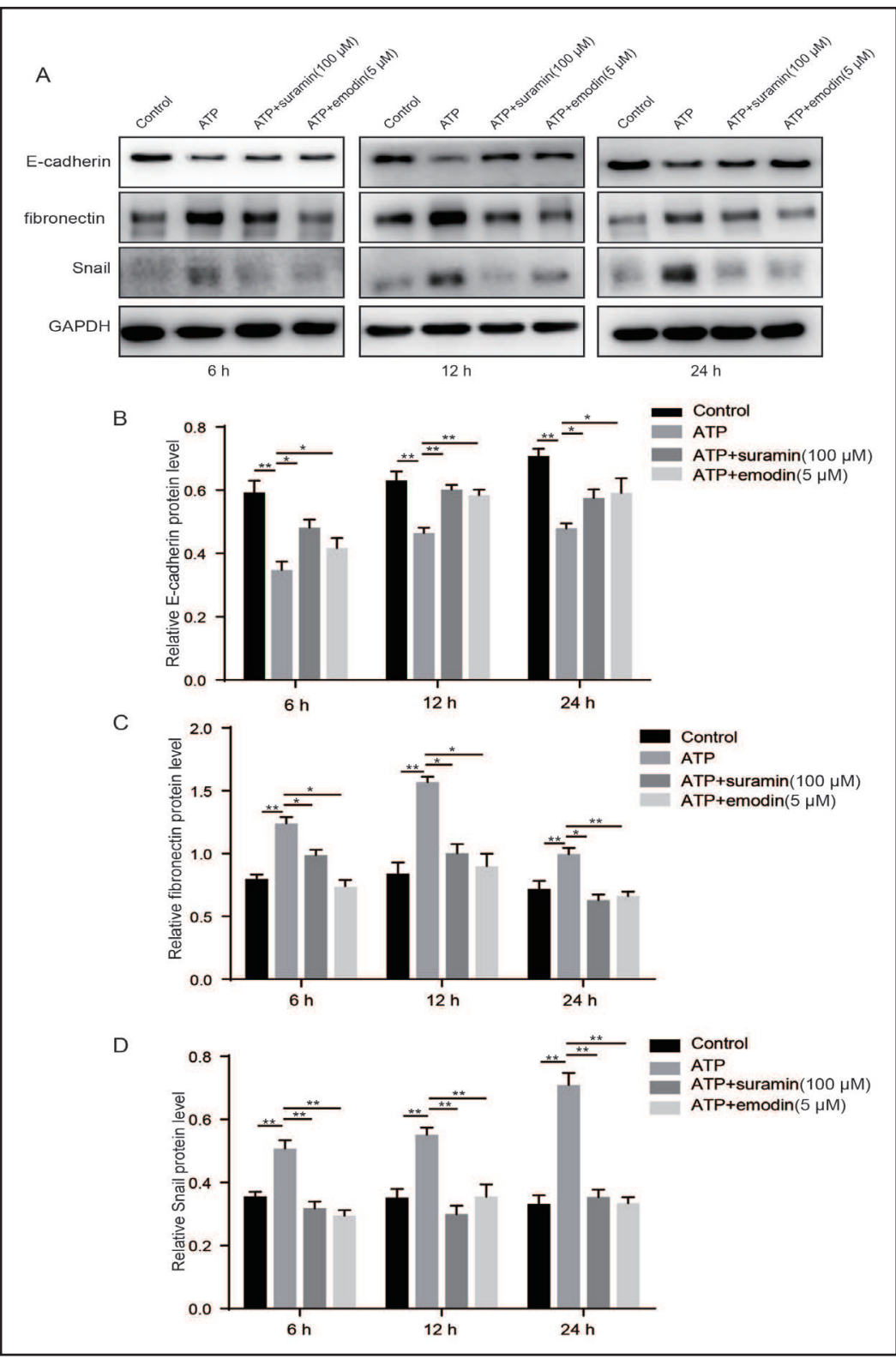

populations in the S phase compared with control. While pretreatment with either emodin or suramin eventually led to an accumulation of cells in the G0/G1 phase and decreased cell populations in S phase (Fig. 2D). These data suggested that emodin inhibited ATP-induced cell proliferation through blocking P2Y-mediated $\mathrm{Ca}^{2+}$ increase and inducing cell cycle arrest in A549 cells.

\section{Emodin inhibited ATP-induced migration in A549 cells.}

Since ATP promotes cell invasion and metastasis through P2Y receptors in prostate cancer cells [13], we tested whether emodin acts as a P2Y antagonist could inhibit ATPinduced migration. Our results showed that emodin as well as suramin inhibited ATP-induced migration (Fig. 3A-D), indicating that emodin may inhibit ATP-induced migration by blocking P2Y receptors. As it is well documented that mitochondrial signaling pathway crucially participates in cell apoptosis [26], we examined the expression level in apoptosis-related proteins within the mitochondrial pathway to elucidate the intracellular signaling pathway. Immunoblotting data suggested that ATP $(100 \mu \mathrm{M})$ treatment increased the expression of 


\section{Cellular Physiology Cell Physiol Biochem 2017;44:1337-1351 \begin{tabular}{l|l|l|l}
\hline DOI: 10.1159/000485495 & () 2017 The Author(s). Published by S. Karger AG, Basel
\end{tabular}

Fig. 5. Emodin inactivated $\mathrm{Ca}^{2+}$ dependent NF- $\mathrm{KB}$ signaling pathways.(A) Immunofluorescence staining of NF- $\kappa$ B was performed. ATP significantly promoted translocation of NF-кB/P65 from cytoplasm to nuclear. Treatment of emodin inhibited ATP induced translocation of NF-kB/P65, which was consistent with the effect of suramin. Original magnification, $\times 400$. (B-C) Representative images and summarized data showing the expression levels of p-NF- $\kappa$ B and NF- $\kappa$ B. A549 cells were treated with and without ATP $(100 \mu \mathrm{M})$ and/or suramin, emodin. The expression level of $\mathrm{p}-\mathrm{NF}-\kappa \mathrm{B}$ was normalized to GAPDH level. ATP stimulation increased the expression of p-NF$\kappa \mathrm{B} / \mathrm{P} 65$. However, treatment with suramin and emodin caused a significant decreased expression of $\mathrm{p}-\mathrm{NF}-\mathrm{\kappa B} / \mathrm{P} 65$. Values are mean $\pm \mathrm{SD}, \mathrm{n}=6,{ }^{* *} \mathrm{P}<0.01,{ }^{* * *} \mathrm{P}<0.001$

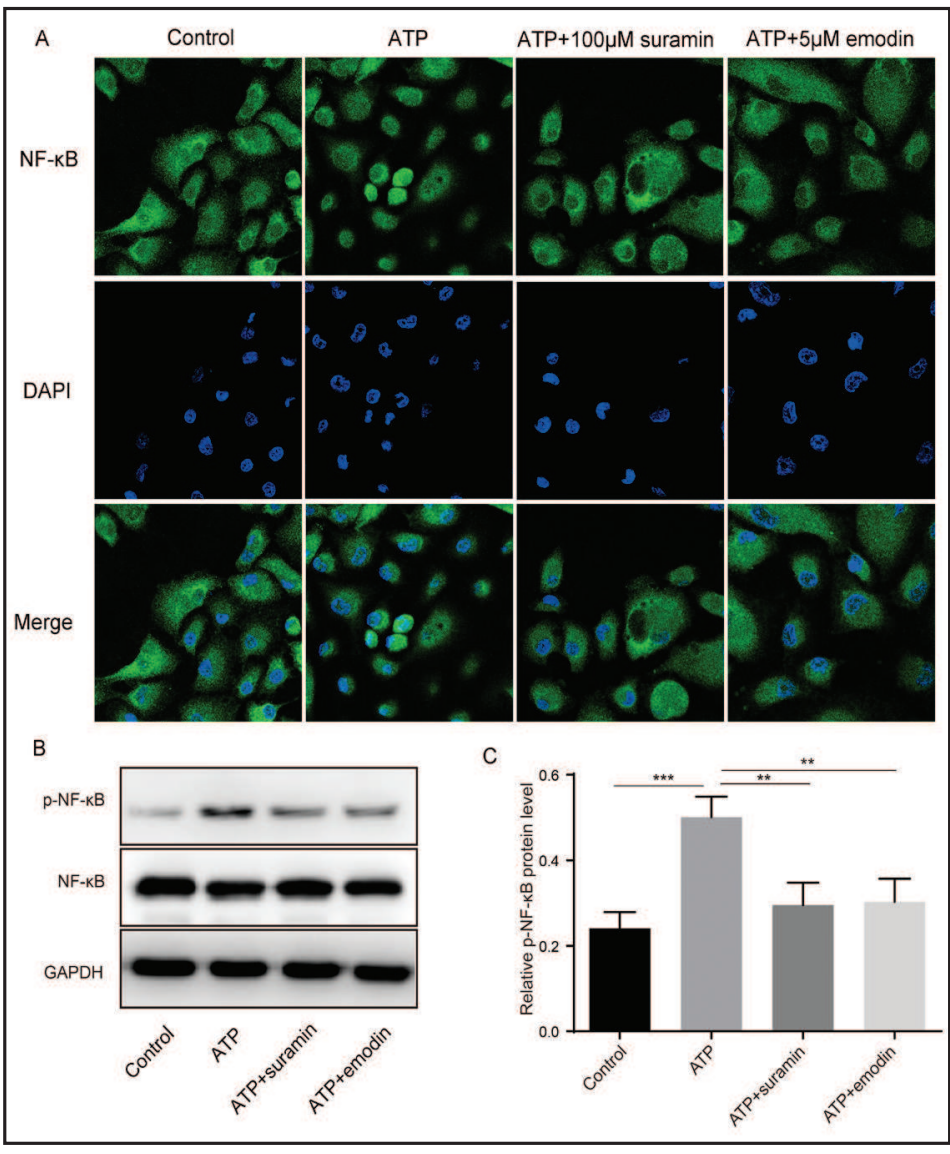

Bcl-2 but decreased the expression of Bax and migration-related protein claudin-1. However, treatment with either suramin or emodin $(5 \mu \mathrm{M})$ caused a significant decrease in Bcl-2 while increase in Bax and claudin-1. These data suggested that emodin reversed ATP-induced protein level changes of Bcl-2, Bax, claudin-1 (Fig. 3E-I).

Emodin inhibited ATP-induced EMT in A549 cells.

EMT is a frequent behavior which can enhance cancer cell migration and invasion $[27,28]$. To determine the effect of ATP and emodin on EMT of A549 cells, we examined expression of mesenchymal markers fibronectin, Snail and epithelia marker E-cadherin. ATP $(100 \mu \mathrm{M})$ treatment for $6 \mathrm{~h}, 12 \mathrm{~h}, 24 \mathrm{~h}$ increased expression of mesenchymal markers, fibronectin and Snail, but decreased the expression of E-cadherin, which is defined as cellcell adhesion protein (Fig. 4). Emodin suppressed ATP-induced EMT after stimulation of $6 \mathrm{~h}$, $12 \mathrm{~h}$, and $24 \mathrm{~h}$, which was consistent with suramin (Fig. 4). Thus, we suggested that emodin inhibited ATP-induced EMT and invasion of A549 cells via antagonizing P2Y receptors.

\section{Emodin suppressed ATP-activated $\mathrm{Ca}^{2+}$ dependent $\mathrm{NF}-\kappa B$ signaling.}

In A549 cells, a $\mathrm{Ca}^{2+}$-dependent activation of $\mathrm{NF}-\kappa \mathrm{B}$ may be one of the main signaling pathways [5]. Therefore, we investigated whether emodin inhibited ATP-induced activation of $\mathrm{Ca}^{2+}$ dependent NF- $\mathrm{BB}$ signaling in A549 cells. As the results showed, ATP significantly promoted translocation of NF- $\mathrm{KB} / \mathrm{P} 65$ from cytoplasm to nuclear when compared with control cells. However, NF- $\kappa \mathrm{B} / \mathrm{P} 65$ was detected largely in the cytoplasm after emodin treatment, consistent with the effect of suramin (Fig 5A). Besides, ATP stimulation increased the expression of $\mathrm{p}-\mathrm{NF}-\kappa \mathrm{B} / \mathrm{P} 65$. However, treatment with suramin and emodin caused a significant decreased p-NF- $\kappa$ B/P65 expression (Fig 5B-C). These data suggested that emodin inhibits ATP-induced activation of $\mathrm{Ca}^{2+}$ dependent $\mathrm{NF}-\kappa \mathrm{B}$ signaling pathway in A549 cells. 


\section{Cellular Physiology \\ Cell Physiol Biochem 2017:44:1337-1351 and Biochemistry

Fig. 6. $\mathrm{NF}-\kappa \mathrm{B}$ inhibitor PDTC blocked ATP-induced proliferation and migration in A549 cells. (A) Proliferation of A549 cells was measured by CCK-8, after treatment with PDTC alone, stimulation with ATP at presence and absence of PDTC. Treatment with PDTC alone had no discernible effect on A549 cell viability while PDTC significantly decreased ATP-induced cell viability. Values are means $\pm \mathrm{SD}, \mathrm{n}=6,{ }^{*} \mathrm{P}<0.05$. (B) Wound healing assay was used to assess the effect of PDTC on A549 cells migration. The wound closure was photographed at post-scratching 0 h, 6 h, 12 h, 24 h. Original magnification, $\times 50$. (C-E) The group data from $B$. Values are mean $\pm \mathrm{SD}, \mathrm{n}=$ $6,{ }^{*} \mathrm{P}<0.05,{ }^{* * *} \mathrm{P}<0.001$.

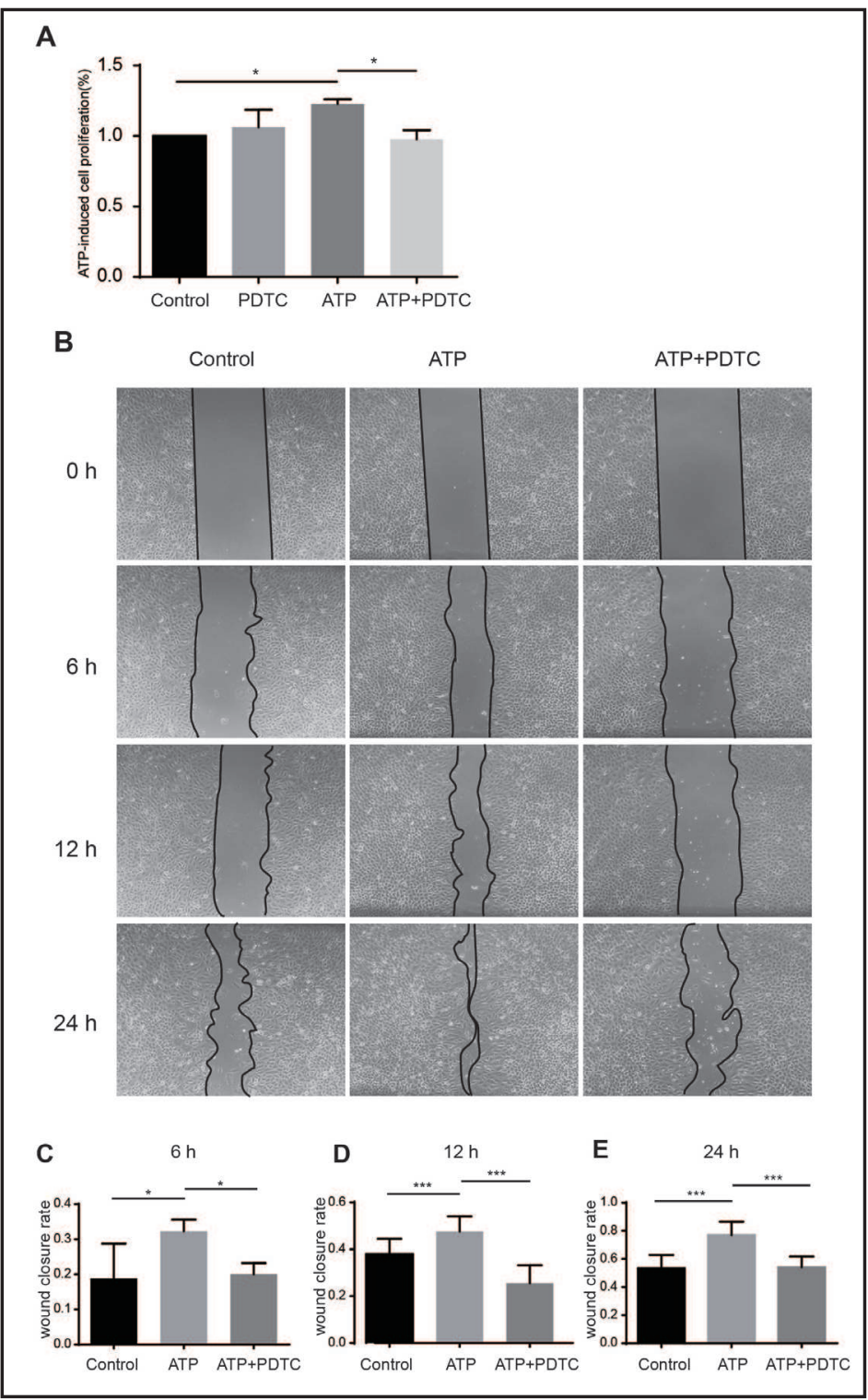

Inhibition of NF- $\kappa B$ suppressed ATP-induced biological effects in A549 cells

To investigate whether NF- $\kappa B$ signaling is involved in ATP-induced proliferation and migration in A549 cells, Pyrrolidine dithiocarbamate (PDTC, an NF- $\kappa$ B inhibitor), was applied to address the effect of NF- $\kappa$ B. A549 cells were treated with PDTC $(20 \mu \mathrm{M})$ and then stimulated with ATP $(100 \mu \mathrm{M})$ for $6 \mathrm{~h}, 12 \mathrm{~h}, 24 \mathrm{~h}$. Treatment with PDTC alone had no discernible effect on A549 cells proliferation or viability while it significantly decreased ATP-induced proliferation and viability (Fig. 6). This result indicated inhibition of NF- $\mathrm{kB}$ suppressed ATP-induced proliferation and migration, therefore NF- $\kappa B$ signaling is involved in ATP-induced reactions in A549 cells.

Since it has been demonstrated that inhibition of NF- $\mathrm{KB}$ suppressed ATP-induced proliferation and migration, we next examined effect of NF- $\mathrm{KB}$ on Bcl-2, Bax and claudin-1. ATP increased the expression of Bcl-2 but decreased the expression of Bax. However, treatment with PDTC caused a significant decrease in Bcl-2 while increase in Bax. Additionally, pretreatment with PDTC before stimulation with ATP significantly up-regulated protein level of claudin-1 (Fig. 7). These data suggested that inhibition of NF- $\mathrm{KB}$ repressed ATP-induced protein level change of Bcl-2, Bax and claudin-1. 


\section{Cellular Physiology and Biochemistry}

Cell Physiol Biochem 2017;44:1337-1351

Fig. 7.NF- $\kappa$ B inhibitor suppressed ATP-induced expression of Bcl-2, Bax, claudin-1.(A) A549 cells were treated with and wihout ATP $(100$ $\mu \mathrm{M}$ ) and/or PDTC. Expression of Bcl-2, Bax, claudin-1 were analyzed by western blot. (B-E) summarized data showing the quantitative densitometry of different samples. Expression of Bcl-2, Bax, claudin-1 were normalized to GAPDH level in the same sample. ATP increased the expression of Bcl-2 but decreased the expression of Bax. However, treatment with PDTC caused a significant decrease in Bcl-2 while increase in Bax. Additionally, pretreatment with PDTC before stimulation with ATP significantly up-regulated protein level of claudin-1. Values are shown as the mean $\pm \mathrm{SD} . \mathrm{n}=6 .{ }^{*} \mathrm{P}<0.05$, ** $\mathrm{P}<0.01$.

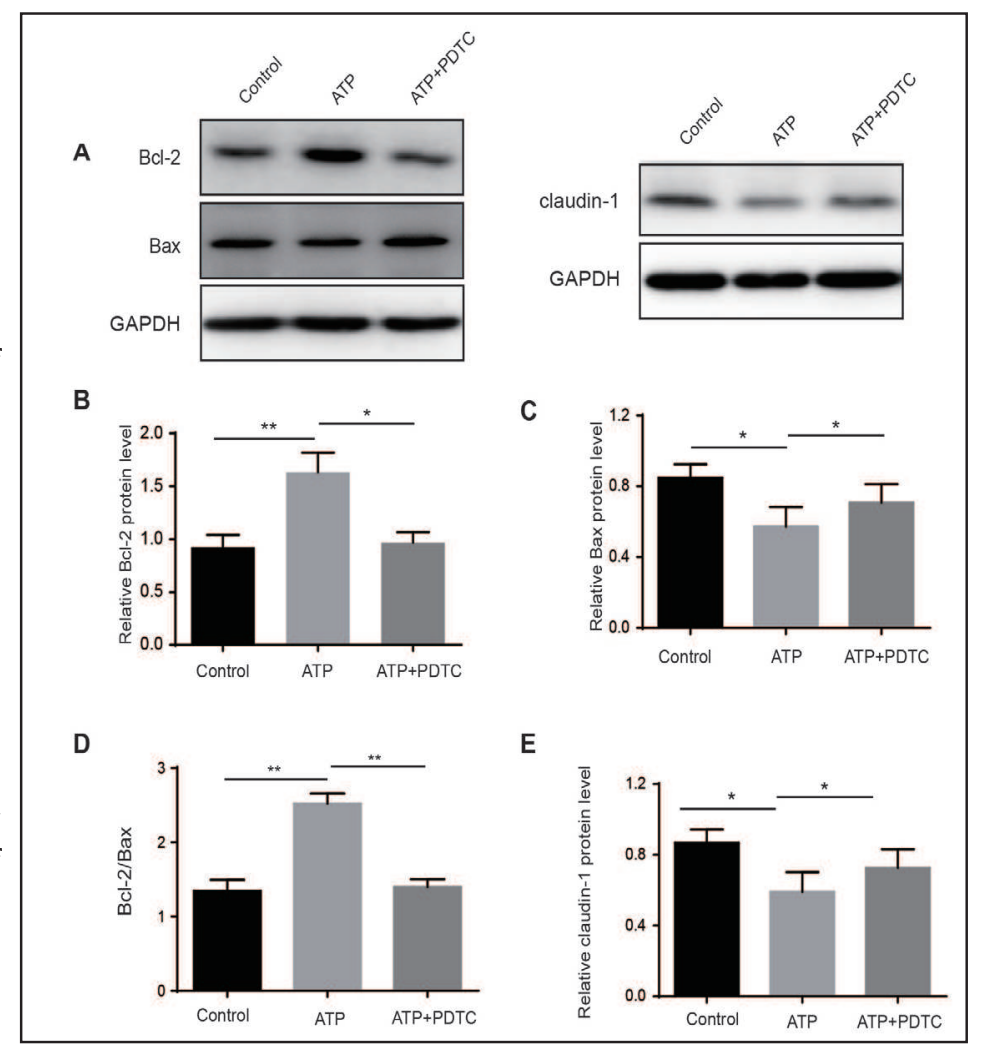

To identify whether NF- $\mathrm{BB}$ is involved in EMT induced by ATP in A549 cells, PDTC was applied before stimulation with ATP. Then we measured the expression of E-cadherin, fibronectin, Snail by western blot (Fig. 8). PDTC suppressed ATP-induced EMT significantly at $6 \mathrm{~h}, 12 \mathrm{~h}$, and $24 \mathrm{~h}$. As verified above, NF- $\mathrm{\kappa B}$ signaling is involved in ATP-induced proliferation and migration, thus we demonstrated that emodin also prevented ATP-induced EMT of A549 cells via inhibition of NF- $\kappa$ B signaling.

\section{Discussion}

It is well known that intratumoral ATP concentration is much higher than that of normal tissues [29]. The elevated concentration of ATP is found to act as a stimulus in the cancer progression [30]. Additionally, extracellular ATP enhances migration of cancer cells, which is a crucial determinant of cancer invasion and metastasis [31]. Although emodin has been shown to suppress lung cancer metastasis, the inhibitory effect of emodin on ATP-induced promotion of cell survival via regulation of $\left[\mathrm{Ca}^{2+}\right]_{\mathrm{i}}$ and NF- $\kappa \mathrm{B}$ signaling pathways in lung cancer cells has not been reported. In the present work, we aim to investigate the effects of emodin on cell proliferation and migration by detecting the influences of emodin on P2Y receptors-mediated $\left[\mathrm{Ca}^{2+}\right]_{\mathrm{i}}$ increase and NF- $\mathrm{KB}$ signaling pathway.

Several subtypes of P2Y receptors such as P2Y1, P2Y2, P2Y4, P2Y6 and P2Y13 were found to be existed in human lungs [4]. In the present study, we examined the expression of different subtypes of P2Y receptors in A549 cells. Our results indicated that P2Y2 and P2Y6 are abundant in this cell line (Fig.1A). In airway epithelial cells, extracellular ATP or UTP regulates intracellular response via P2Y2 and P2Y1 receptors [32]. Our data showed that both ATP and UTP, agonists of P2Y receptors, evoked a strong elevation of $\left[\mathrm{Ca}^{2+}\right]_{\mathrm{i}}$. The results demonstrate that ATP-induced $\left[\mathrm{Ca}^{2+}\right]_{\mathrm{i}}$ increase mainly through activation of P2Y receptors in A549 cells. It is reported that intracellular $\mathrm{Ca}^{2+}$ could promote radioresistance of NSCLC cells [33]. Elevation of $\left[\mathrm{Ca}^{2+}\right]_{i}$ stimulates lung cancer cells proliferation by promoting cell 


\section{Cellular Physiology \\ Cell Physiol Biochem 2017:44:1337-1351 and Biochemistry

Fig. 8. NF- $\kappa B$ inhibitor suppressed ATP-induced EMT.(A) The protein expression was measured by stimulating with and wihout ATP $(100 \mu \mathrm{M})$ and/or PDTC. Representative images of EMT markers proteins including E-cadherin, fibronectin and Snail. PDTC suppressed ATP-induced EMT. (B-D) The expression levels of E-cadherin, fibronectin, Snail were normalized to GAPDH level in the same sample. Values are shown as the mean $\pm \mathrm{SD} . \mathrm{n}=6 .{ }^{*} \mathrm{P}<0.05$, ${ }^{* *} \mathrm{P}<0.01$.

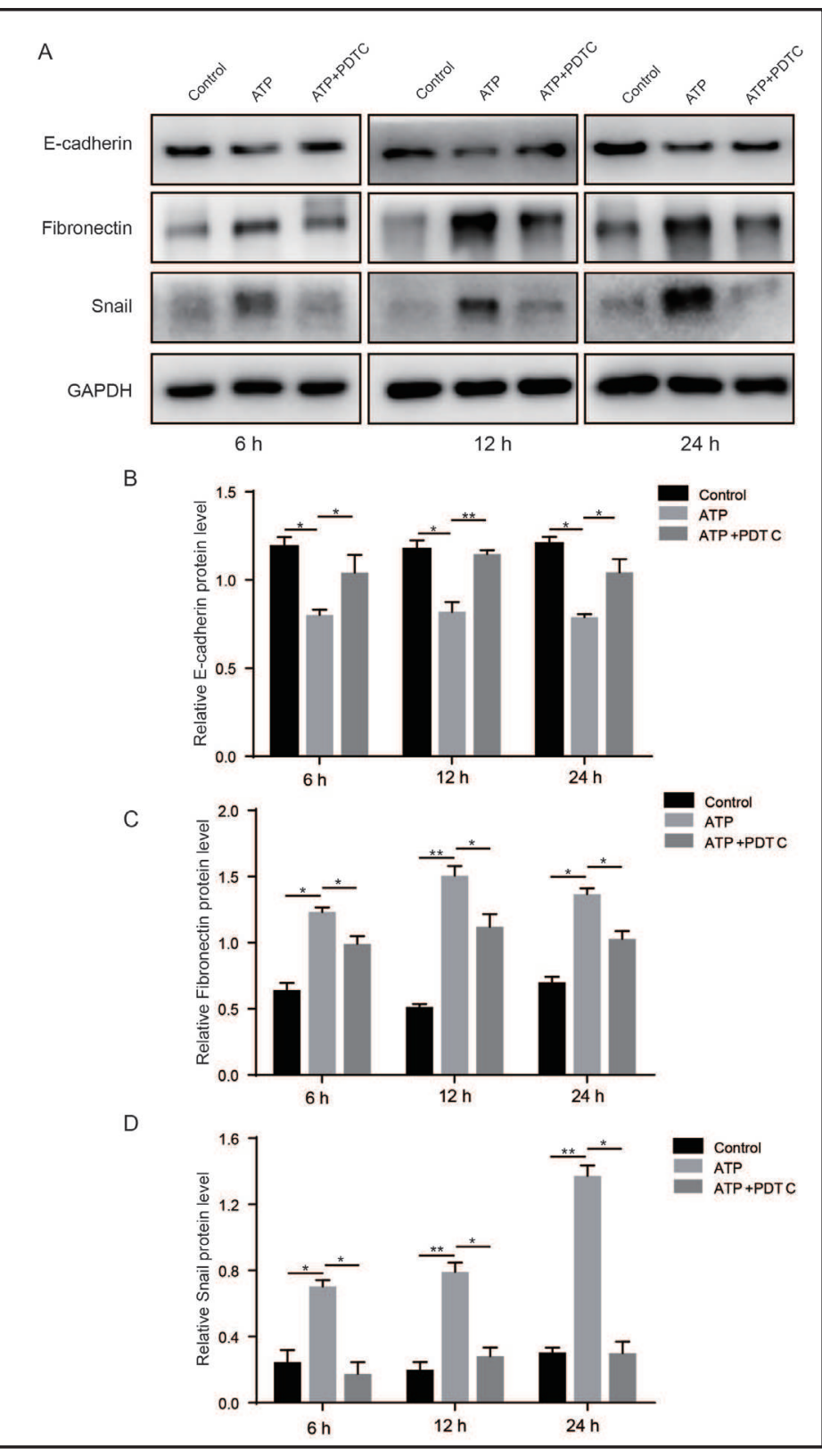

cycle progression [34]. That implicates that $\mathrm{Ca}^{2+}$ plays critical role in progression of lung cancer cells. Then the effect of emodin on ATP/UTP-induced $\left[\mathrm{Ca}^{2+}\right]_{\mathrm{i}}$ increase (Fig. 1B-E) was observed. Moreover, the efficient inhibition of emodin on P2Y-mediated calcium response was similar to that of the nonselective P2Y receptors inhibitor, suramin (Fig. 1B-D). These results suggest that emodin may inhibit ATP-induced $\left[\mathrm{Ca}^{2+}\right]_{i}$ increase via blocking P2Y receptors.

P2Y receptors are involved in mediating cell growth of melanoma, lung cancer, breast cancer [5, 35-37]. Extracellular ATP leads to increase of intracellular ATP concentration, thus promotes cell growth and survival of A549 cells [29]. Recent study shows that emodin inhibits cell proliferation by modulating cell cycle markers expression during oral carcinogenesis [38]. Subsequently, we investigated the effect of emodin on ATP-induced proliferation in A549 cells. We found that ATP promoted A549 cells proliferation time dependently. Consistently, ATP accelerated DNA synthesis of A549 cells, thus caused an obvious increase of cell population in the S phase (Fig. 2D). Emodin and suramin inhibited ATP-induced proliferation in a concentration-dependent manner through decreasing cell population of $\mathrm{S}$ phase, thus 


\section{Cellular Physiology Cell Physiol Biochem 2017;44:1337-1351

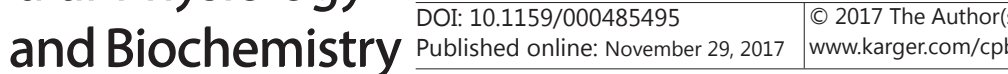 \\ Wang et al.: The Effect of Emodin on Inhibiting Lung Cancer Cells Progression}

led to accumulation of cells in G0/G1 (Fig. 2C, D). Our data on this profile was in agreement with a previous study that in lung squamous cell carcinomas, emodin has been reported in cancer prevention [39]. Besides, emodin triggers apoptosis of human lung cancer cells through a ROS-dependent signaling pathway [22]. These data suggests that the inhibitory effect of emodin on cell cycle may lead to suppression of ATP-induced proliferation.

In order to investigate the molecular mechanism of emodin on ATP-induced proliferation and migration, we determined related protein level of ATP downstream. The expression of claudin-1, which has significant roles in migration and metastasis, antiapoptotic protein Bcl2 , proapoptotic protein Bax is examined. We found that stimulation with ATP dramatically up-regulated Bcl-2 expression and down-regulated the expression level of Bax and claudin-1 as shown in Fig. 3E. It has been reported that ATP promotes A549 cell survival via regulation of $\left[\mathrm{Ca}^{2+}\right]_{i}$ and increase of $\mathrm{Bcl}-2 / \mathrm{Bax}$ ratio [9]. That implies elevation of $\mathrm{Bcl}-2 / \mathrm{Bax}$ ratio by high extracellular ATP may be an important latent reason for promoting cancer cells progression. Besides, we found that emodin and suramin treatment before ATP stimulation up-regulates the protein level of claudin-1 and Bax, down-regulates the protein level of Bcl-2. In prostate cancer cells, decreased expression of claudin-1 by ATP leads to invasiveness and EMT [13]. Based on data above, we conclude that emodin inhibits ATP-induced up-regulation of Bcl-2/ Bax ratio and down-regulation of claudin-1 by antagonizing P2Y receptors.

Calcium signal plays critical role in the cancer progression, and is also required for the occurrence of EMT [6]. It is well accepted that EMT participates in tumour progression and metastasis formation [40]. Inhibition of EMT can repress lung cancer cells invasion [11]. Moreover, in the peripheral leading edge of NSCLC, the expression of EMT biomarkers (vimentin and N-cadherin) is markedly high [41]. In addition emodin ameliorates high glucose induced-podocyte EMT in vitro and in vivo [42]. Thus, we wonder whether EMT is induced by ATP stimulation and inhibited by emodin treatment. Our data showed that ATP caused gradually lessened expression of epithelial marker, E-cadherin and increased expression of mesenchymal markers, fibronectin, Snail significantly. However, such ATPinduced protein level change was suppressed by emodin, suggesting that emodin represses ATP-induced lung cancer cells progression via inhibition of EMT (Fig. 4).

Recent studies have demonstrated UTP-induced activation of nuclear factor (NF- $\kappa \mathrm{B}$ ) in activated T cells [43]. Emodin protects against concanavalin A-induced hepatitis through inhibiting activation of the p38 MAPK-NF- $\kappa B$ signaling pathway in mice [44]. In prostate cancer cells, inhibition of NF- $\mathrm{KB}$ signaling pathway suppresses cell proliferation and induces cell cycle arrest in G2/M phase associated with regulation of Bcl-2 family proteins (Bcl2, Bax) [8]. What's more, P2Y receptors-induced proliferation of A549 cells depends on activation of NF- $\mathrm{KB}$ [5], which promotes transcription of downstream target genes such as Bax [7]. Therefore we detected the effect of emodin on ATP-induced activation of NF- $\kappa B$ and found that ATP significantly promoted translocation of NF- $\kappa$ B from cytoplasm to nuclear, while, emodin and suramin treatment inhibited this effect (Fig. 5). That is in agreement with a previous study that in human skin squamous cell carcinoma, emodin was detected to inhibit TPA-induced nuclear translocation of p65 and NF-кB DNA-binding activity [45]. The results demonstrate that emodin suppresses ATP-induced activation of $\mathrm{Ca}^{2+}$ - dependent NF$\kappa \mathrm{B}$ signaling pathways. Thus it indicates that emodin acts as a P2Y blocker and contributes to inactivation of NF- $\mathrm{\kappa B}$.

In order to explicate whether NF- $\kappa \mathrm{B}$ participate in ATP-induced proliferation and migration, we applied an NF- $\kappa B$ inhibitor, PDTC. Our data revealed that PDTC treatment inhibited ATP-induced proliferation and migration remarkably (Fig. 6). The role of claudin-1, Bcl-2, Bax in NF- $\kappa$ B signaling pathway in A549 cells has not been reported, previously. Recent study demonstrated that inhibition of NF- $\kappa \mathrm{B}$ can ameliorate gastric destruction by increasing protein level of claudin-1 [46]. In this case, we examined the protein level change of Bcl-2, Bax and claudin- 1 in the presence and absence of PDTC before ATP stimulation. Our results showed that inhibition of NF- $\mathrm{kB}$ increased the expression of claudin- 1 and Bax and decreased the expression of Bcl-2 (Fig. 7) thus inhibited ATP-induced cell proliferation and migration (Fig. 6). It is documented that suppression of NF- $\mathrm{KB}$ inhibits prostate cancer growth and 


\section{Cellular Physiology Cell Physiol Biochem 2017;44:1337-1351 \begin{tabular}{ll|l} 
DOI: 10.1159/000485495 & $\begin{array}{l}\text { C 2017 The Author(s). Published by S. Karger AG, Basel } \\
\text { www.karger.com/cpb }\end{array}$ \\
\hline
\end{tabular} \\ Wang et al.: The Effect of Emodin on Inhibiting Lung Cancer Cells Progression}

EMT in prostate cancer cells [47]. Inhibition of NF- $\mathrm{KB}$ leads to deregulation of EMT and neural invasion in pancreatic cancer [48]. In our study, we found the expression of epithelial marker, E-cadherin was increased and the mesenchymal markers, fibronectin and Snail were decreased after inhibition of NF- $\kappa$ B. Therefore, inactivation of NF- $\kappa B$ also led to inhibition of EMT provoked by ATP (Fig. 8).

Thus, we conclude that emodin may act as a latent therapeutic drug for the treatment of lung cancer, whose advantage lies in the following aspects: the safety of emodin has been long demonstrated. In addition, it is economical and practical with regard to patients, because it can be obtained from plants with high content of emodin.

Nevertheless, we have to point out the limitation in our investigation is that we did not examine the effects of emodin on lung cancer in vivo, whether it plays protective role in treating lung cancer remains unknown. Therefore it is necessary to further explore its biological function and action mechanism in anti-cancer in vivo.

In summary, our results indicates that high concentration of extracellular ATP promotes proliferation, migration, EMT of A549 cells by activating P2Y receptors, inducing $\left[\mathrm{Ca}^{2+}\right]_{\mathrm{i}}$ increase and activating NF- $\kappa$ B signaling. Additionally, our data confirms that emodin inhibits activation of P2Y-receptors/NF- $\kappa$ B pathway as well as ATP-induced carcinogenic effect (Fig. 9). Taken together, emodin may be a potent P2Y antagonist and suppresses ATP-induced proliferation and migration by inhibiting P2Y-mediated $\left[\mathrm{Ca}^{2+}\right]_{\mathrm{i}}$ increase and NF- $\mathrm{KB}$ activation.

\section{Acknowledgements}

We are grateful to the Grant support from National Natural Science Foundation of China (NO. 81470203), (NO. 81500048).

\section{Disclosure Statement}

The authors declare no Disclosure Statement.

\section{References}

1 Siegel RL, Miller KD, Jemal A: Cancer Statistics, 2017. CA Cancer J Clin 2017;67:7-30.

2 Pellegatti P, Raffaghello L, Bianchi G, Piccardi F, Pistoia V, Di Virgilio F: Increased level of extracellular ATP at tumor sites: In vivo imaging with plasma membrane luciferase. PLoS One 2008;3:e2599.

-3 Bours MJ, Dagnelie PC, Giuliani AL, Wesselius A, Di Virgilio F: P2 receptors and extracellular ATP: A novel homeostatic pathway in inflammation. Front Biosci (Schol Ed) 2011;3:1443-1456.

4 Ralevic V, Burnstock G: Receptors for purines and pyrimidines. Pharmacol Rev 1998;50:413-492.

5 Schafer R, Sedehizade F, Welte T, Reiser G: ATP- and UTP-activated P2Y receptors differently regulate proliferation of human lung epithelial tumor cells. Am J Physiol Lung Cell Mol Physiol 2003;285:L376-L385. 


\section{Cellular Physiology Cell Physiol Biochem 2017;44:1337-1351 \begin{tabular}{l|l|l}
\hline DOI: 10.1159/000485495 & ( ) 2017 The Author(s). Published by S. Karger AG, Basel
\end{tabular}

6 Prevarskaya N, Skryma R, Shuba Y: Calcium in tumour metastasis: New roles for known actors. Nat Rev Cancer 2011;11:609-618.

7 Verma A, Kushwaha HN, Srivastava AK, Srivastava S, Jamal N, Srivastava K, Ray RS: Piperine attenuates UV-R induced cell damage in human keratinocytes via NF-kB, Bax/Bcl-2 pathway: An application for photoprotection. J Photochem Photobiol B 2017;172:139-148.

-8 Liu Y, Gao X, Deeb D, Zhang Y, Shaw J, Valeriote FA, Gautam SC: Mycotoxin verrucarin a inhibits proliferation and induces apoptosis in prostate cancer cells by inhibiting prosurvival Akt/NF-kB/mTOR signaling. J Exp Ther Oncol 2016;11:251-260.

-9 Song S, Jacobson KN, McDermott KM, Reddy SP, Cress AE, Tang H, Dudek SM, Black SM, Garcia JG, Makino A, Yuan JX: ATP promotes cell survival via regulation of cytosolic [Ca2+] and Bcl-2/Bax ratio in lung cancer cells. Am J Physiol Cell Physiol 2016;310:C99-C114.

10 Ko H, So Y, Jeon H, Jeong MH, Choi HK, Ryu SH, Lee SW, Yoon HG, Choi KC: TGF-beta1-induced epithelialmesenchymal transition and acetylation of Smad2 and Smad3 are negatively regulated by EGCG in human A549 lung cancer cells. Cancer Lett 2013;335:205-213.

11 Shen L, Chen L, Wang Y, Jiang X, Xia H, Zhuang Z: Long noncoding RNA MALAT1 promotes brain metastasis by inducing epithelial-mesenchymal transition in lung cancer. J Neurooncol 2015;121:101-108.

12 Tischler V, Pfeifer M, Hausladen S, Schirmer U, Bonde AK, Kristiansen G, Sos ML, Weder W, Moch H, Altevogt P, Soltermann A: L1CAM protein expression is associated with poor prognosis in non-small cell lung cancer. Mol Cancer 2011;10:127.

-13 Li WH, Qiu Y, Zhang HQ, Liu Y, You JF, Tian XX, Fang WG: P2Y2 receptor promotes cell invasion and metastasis in prostate cancer cells. Br J Cancer 2013;109:1666-1675.

14 Zheng L, Li Y, Li X, Kou J, Zhong Z, Jiang Y, Liu Z, Tian Y, Yang L: Combination of hydroxyl acetylated curcumin and ultrasound induces macrophage autophagy with Anti-Apoptotic and Anti-Lipid aggregation effects. Cell Physiol Biochem 2016;39:1746-1760.

15 Wang HH, Chung JG: Emodin-induced inhibition of growth and DNA damage in the Helicobacter pylori. Curr Microbiol 1997;35:262-266.

16 Chang CH, Lin CC, Yang JJ, Namba T, Hattori M: Anti-inflammatory effects of emodin from ventilago leiocarpa. Am J Chin Med 1996;24:139-142.

17 Sato M, Maulik G, Bagchi D, Das DK: Myocardial protection by protykin, a novel extract of trans-resveratrol and emodin. Free Radic Res 2000;32:135-144.

18 Mischitelli M, Jemaa M, Almasry M, Faggio C, Lang F: Triggering of erythrocyte cell membrane scrambling by emodin. Cell Physiol Biochem 2016;40:91-103.

19 Nemmar A, Al DR, Alamiri J, Al HS, Al SH, Beegam S, Yuvaraju P, Yasin J, Ali BH: Diesel exhaust particles induce impairment of vascular and cardiac homeostasis in mice: Ameliorative effect of emodin. Cell Physiol Biochem 2015;36:1517-1526.

-20 Tabolacci C, Lentini A, Mattioli P, Provenzano B, Oliverio S, Carlomosti F, Beninati S: Antitumor properties of aloe-emodin and induction of transglutaminase 2 activity in B16-F10 melanoma cells. Life Sci 2010;87:316-324.

21 Chen YY, Chiang SY, Lin JG, Ma YS, Liao CL, Weng SW, Lai TY, Chung JG: Emodin, aloe-emodin and rhein inhibit migration and invasion in human tongue cancer SCC-4 cells through the inhibition of gene expression of matrix metalloproteinase-9. Int J Oncol 2010;36:1113-1120.

-22 Su YT, Chang HL, Shyue SK, Hsu SL: Emodin induces apoptosis in human lung adenocarcinoma cells through a reactive oxygen species-dependent mitochondrial signaling pathway. Biochem Pharmacol 2005;70:229241.

-23 Tang Q, Wu J, Zheng F, Hann SS, Chen Y: Emodin increases expression of Insulin-Like growth factor binding protein 1 through activation of MEK/ERK/AMPKalpha and interaction of PPARgamma and sp1 in lung cancer. Cell Physiol Biochem 2017;41:339-357.

24 Qian Y, Wang X, Li Y, Cao Y, Chen X: Extracellular ATP a new player in cancer metabolism: NSCLC cells internalize ATP in vitro and in vivo using multiple endocytic mechanisms. Mol Cancer Res 2016;14:10871096.

25 Clunes MT, Kemp PJ: P2u purinoceptor modulation of intracellular Ca2+ in a human lung adenocarcinoma cell line: Down-regulation of Ca2+ influx by protein kinase C. Cell Calcium 1996;20:339-346.

-26 Walia V, Kakar S, Elble R: Micromanagement of the mitochondrial apoptotic pathway by p53. Front Biosci (Landmark Ed) 2011;16:749-758. 


\section{Cellular Physiology Cell Physiol Biochem 2017;44:1337-1351 \begin{tabular}{l|l|l}
\hline DOI: 10.1159/000485495 & ( ) 2017 The Author(s). Published by S. Karger AG, Basel
\end{tabular}

Wang et al.: The Effect of Emodin on Inhibiting Lung Cancer Cells Progression

27 Thiery JP, Acloque H, Huang RY, Nieto MA: Epithelial-mesenchymal transitions in development and disease. Cell 2009;139:871-890.

28 Giannelli G, Koudelkova P, Dituri F, Mikulits W: Role of epithelial to mesenchymal transition in hepatocellular carcinoma. J Hepatol 2016;65:798-808.

-29 Qian Y, Wang X, Liu Y, Li Y, Colvin RA, Tong L, Wu S, Chen X: Extracellular ATP is internalized by macropinocytosis and induces intracellular ATP increase and drug resistance in cancer cells. Cancer Lett 2014;351:242-251.

-30 Pellegatti P, Raffaghello L, Bianchi G, Piccardi F, Pistoia V, Di Virgilio F: Increased level of extracellular ATP at tumor sites: In vivo imaging with plasma membrane luciferase. PLoS One 2008;3:e2599.

-31 Gupta GP, Massague J: Cancer metastasis: Building a framework. Cell 2006;127:679-695.

-32 Homolya L, Steinberg TH, Boucher RC: Cell to cell communication in response to mechanical stress via bilateral release of ATP and UTP in polarized epithelia. J Cell Biol 2000;150:1349-1360.

-33 Wang Y, He J, Zhang S, Yang Q: Intracellular calcium promotes radioresistance of non-small cell lung cancer A549 cells through activating Akt signaling. Tumour Biol 2017;39:1393393694.

34 Yang LL, Liu BC, Lu XY, Yan Y, Zhai YJ, Bao Q, Doetsch PW, Deng X, Thai TL, Alli AA, Eaton DC, Shen BZ, Ma HP: Inhibition of TRPC6 reduces non-small cell lung cancer cell proliferation and invasion. Oncotarget 2017;8:5123-5134.

-35 Azimi I, Beilby H, Davis FM, Marcial DL, Kenny PA, Thompson EW, Roberts-Thomson SJ, Monteith GR: Altered purinergic receptor- $\mathrm{Ca}(2)(+)$ signaling associated with hypoxia-induced epithelial-mesenchymal transition in breast cancer cells. Mol Oncol 2016;10:166-178.

-36 Jin H, Eun SY, Lee JS, Park SW, Lee JH, Chang KC, Kim HJ: P2Y2 receptor activation by nucleotides released from highly metastatic breast cancer cells increases tumor growth and invasion via crosstalk with endothelial cells. Breast Cancer Res 2014;16:R77.

-37 White N, Knight GE, Butler PE, Burnstock G: An in vivo model of melanoma: Treatment with ATP. Purinergic Signal 2009;5:327-333.

-38 Manimaran A, Buddhan R, Manoharan S: Emodin downregulates cell proliferation markers during dmba induced oral carcinogenesis in golden syrian hamsters. Afr J Tradit Complement Altern Med 2017;14:8391.

-39 Lee HZ, Hsu SL, Liu MC, Wu CH: Effects and mechanisms of aloe-emodin on cell death in human lung squamous cell carcinoma. Eur J Pharmacol 2001;431:287-295.

40 Christiansen JJ, Rajasekaran AK: Reassessing epithelial to mesenchymal transition as a prerequisite for carcinoma invasion and metastasis. Cancer Res 2006;66:8319-8326.

41 Mahmood MQ Ward C, Muller HK, Sohal SS, Walters EH: Epithelial mesenchymal transition (EMT) and nonsmall cell lung cancer (NSCLC): A mutual association with airway disease. Med Oncol 2017;34:45.

42 Chen T, Zheng LY, Xiao W, Gui D, Wang X, Wang N: Emodin ameliorates high glucose induced-podocyte epithelial-mesenchymal transition in-vitro and in-vivo. Cell Physiol Biochem 2015;35:1425-1436.

$\checkmark 43$ Abbott KL, Loss JN, Robida AM, Murphy TJ: Evidence that Galpha(q)-coupled receptor-induced interleukin-6 mRNA in vascular smooth muscle cells involves the nuclear factor of activated $\mathrm{T}$ cells. Mol Pharmacol 2000;58:946-953.

44 Xue J, Chen F, Wang J, Wu S, Zheng M, Zhu H, Liu Y, He J, Chen Z: Emodin protects against concanavalin A-induced hepatitis in mice through inhibiting activation of the p38 MAPK-NF-kappaB signaling pathway. Cell Physiol Biochem 2015;35:1557-1570.

45 Huang Q Shen HM, Ong CN: Inhibitory effect of emodin on tumor invasion through suppression of activator protein-1 and nuclear factor-kappaB. Biochem Pharmacol 2004;68:361-371.

46 Duan JL, Yin J, Ren WK, Wu MM, Chen S, Cui ZJ, Wu X, Huang RL, Li TJ, Yin YL: Pyrrolidine dithiocarbamate restores gastric damages and suppressive autophagy induced by hydrogen peroxide. Free Radic Res 2015;49:210-218.

47 Zhang J, Kuang Y, Wang Y, Xu Q, Ren Q: Notch-4 silencing inhibits prostate cancer growth and EMT via the NF-kappaB pathway. Apoptosis 2017;22:877-884.

-48 Nomura A, Majumder K, Giri B, Dauer P, Dudeja V, Roy S, Banerjee S, Saluja AK: Inhibition of NF-kappa B pathway leads to deregulation of epithelial-mesenchymal transition and neural invasion in pancreatic cancer. Lab Invest 2016;96:1268-1278. 